\title{
Defining the baseline for river restoration: comparing carabid beetle diversity of natural and human-impacted riparian habitats
}

\author{
Claudia Sprößig ${ }^{1}$ Sascha Buchholz ${ }^{2,3}$ (1) $\cdot$ Frank Dziock $^{1}$
}

Received: 24 January 2020 / Accepted: 6 July 2020 / Published online: 15 July 2020

(c) The Author(s) 2020

\begin{abstract}
Near-natural rivers and riparian ecosystems can represent biodiversity hotspots harbouring many highly specialised, rare and endangered species. During the past centuries, these habitats have been heavily degraded by anthropogenic use, and therefore river restoration is one of the most striking fields of action that is legally defined by the European Union Water Framework Directive. Successful restoration depends on realistic and specified targets that should be defined beforehand and founded on status quo surveys. We present a comparison of carabid beetle communities in riparian habitats of natural and managed river sites of the Mulde River in the Biosphere Reserve Middle Elbe. This endeavour is part of a unique multi-level revitalisation project. Pitfall trapping in 2016 and 2017 yielded 111 carabid species with many species of conservation concern in natural and managed habitats. However, Simpson diversity and functional diversity were lower in the latter. Both habitats harboured specific species assemblages with characteristic indicator species. Additionally, the trap location on slip-off slopes or cut banks was a significant driver of species composition. Our results indicate high ecological development potentials for the Mulde River, but restoration should consider differences between slip-off slopes and cut-off banks. We postulate that future restoration will foster population increases as well as a wider distribution of rare and endangered riparian habitat specialists.
\end{abstract}

Keywords Carabidae $\cdot$ Functional diversity $\cdot$ Ground beetles $\cdot$ Lowland river ecosystem $\cdot$ Mulde river $\cdot$ Riparian habitat

\section{Introduction}

Rivers and adjacent ecosystems, including floodplains and riverbanks, are biodiversity hotspots (Naiman et al. 1993; Hauer et al. 2016) that harbour many highly specialised, rare and endangered species (Anderson and Hanssen 2005; Desender 2005; Denux et al. 2017). Due to flooding, these ecosystems are very dynamic, a feature that is an important driver for typical floodplain and rivershore species (Sienkiewicz and Zmihorski 2011; Fournier et al. 2015). River valleys also play a vital role as migration corridors for plants (Liu et al. 2006; Nobis et al. 2017) and animals (Cormier et al. 2013; Romanowski et al. 2013). Finally, river

Sascha Buchholz

sascha.buchholz@tu-berlin.de

1 University of Applied Sciences HTW Dresden, Pillnitzer Platz 2, 01326 Dresden, Germany

2 Department of Ecology, Technische Universität Berlin, 12165 Berlin, Germany

3 Berlin-Brandenburg Institute of Advanced Biodiversity Research (BBIB), 14195 Berlin, Germany ecosystems provide multiple services that serve the needs of local (and more) residents, for example, carbon dioxide capture, flood retention, landscape aesthetics and recreation (Schindler et al. 2016).

During the past centuries, anthropogenic disturbances and modifications significantly reduced the amount of pristine river ecosystems due to river flow regulations, water pollution, intensified agriculture, urban development and recreation (Karthe et al. 2017). Consequently, more than 50\% of European rivers lost their former habitat quality (EEA 2018). In Germany, almost all rivers are affected by human modifications (Hering et al. 2015). These modifications are further associated with adverse effects of global change (such as invasion of alien species) that negatively affect river ecosystems (Schirmel et al. 2016). Thus, preventing the degradation of river ecosystems and biodiversity loss as well as maintaining ecosystem functions and services are major goals in restoration ecology (Strayer and Dudgeon 2010; Schindler et al. 2016). In Europe, the implementation of the European Union (EU) Water Framework Directive has fostered biodiversity conservation and management policies and actions that make river restoration an overarching 
issue. Therefore, river ecosystems have been increasingly subjected to hydromorphological restructuring, river bank restoration, dam removal and deconstruction of bank reinforcements (Rumm et al. 2016, 2018; Schindler et al. 2016; Scholz et al. 2016; Sneddon et al. 2017; Lorenz et al. 2018).

In central Germany, the Mulde River is in the focus of a comprehensive revitalisation project and a key issue for transregional river restoration efforts (Schulz-Zunkel et al. 2017). The river is part of the Biosphere Reserve Middle Elbe and the cross-border 'Flusslandschaft Elbe' Biosphere Reserve; due to remnant habitats and species as well as natural sections it has good conditions to regain a favourable ecological status of a near-natural river ecosystem and features area-wide habitat connectivity to floodplains and riparian forests (Reichhoff and Refior 1997; Schulz-Zunkel et al. 2017). The 'Wilde Mulde' revitalisation project pursues a multi-level approach, which is unique and has not yet been realised in other river ecosystems. In particular, it combines (a) increasing the amount of dead wood by exposition of logged trees into the river, (b) restoration of riparian habitats and embankment removals, (c) reconnection of the river with old branches and (d) reforestation of riparian forests. Although (a), (c) and (d) do not directly affect riparian habitats and their species communities, it is mandatory to evaluate - and if necessary optimise - the implemented restoration and revitalisation measures by studying the effects on riparian habitats and species communities in monitoring surveys. Furthermore, for successful restoration it is vital to first define realistic and specified targets for certain habitat types in a region. This endeavour could help to set the scene for subsequent restoration activities because it may rely on current environmental conditions and biodiversity patterns in local near-natural river habitats. This information may be related to modified sites under anthropogenic use to derive ecological development potentials and perspectives for the management of indicator species.

Therefore, the aim of the study was to compare riparian habitats with their species communities at natural and managed rivers sites. In particular, we assumed that (1) taxonomic diversity (in terms of number of species and individuals, Simpson diversity) as well as functional diversity is higher in natural sites, (2) importance for conservation (measured as the percentage of species of conservation concern) would be better in natural sites and (3) assemblage structure would be different with distinctive indicator species for different sites (natural/managed).

We referred to carabid beetles as model organisms, because they are proven to be an appropriate taxon for evaluating the ecological status of river ecosystems and studying effects of river restoration (e.g., Januschke et al. 2011, 2014; Januschke and Verdonschot 2016; Gruppe et al. 2017; Paillex et al. 2017; Bednarska et al. 2018). Carabid beetles quickly respond to environmental changes (Gerisch et al.
2006, 2012a; Lambeets et al. 2009), have specific habitat requirements (Günther and Assmann 2005; Kleinwächter and Rickfelder 2007; Paetzold et al. 2008) and comprise numerous well-adapted riparian species (Cartron et al. 2003; Lambeets et al. 2008a; Gerisch et al. 2012b). Therefore, a multi-year carabid beetle sampling was established in line with the restoration of the Mulde riverbanks.

\section{Methods}

\section{Study area and study sites}

We selected two study sites, one in a managed section and one in a natural section located along the Mulde river near Dessau in Saxony-Anhalt (Germany) (Fig. 1). The Mulde is a typical low-mountain-range river with periodic highwater levels in the spring, autumn and winter (Reichhoff and Refior 1997). With an average annual rainfall of $550 \mathrm{~mm}$ and a temperature amplitude of $18.6{ }^{\circ} \mathrm{C}$ (min: $-0.1{ }^{\circ} \mathrm{C}$; max: $18.5^{\circ} \mathrm{C}$ ), the study area is situated in the eastern part of the Central Germany dry region and touches the border of the subcontinental climate sphere (Warthemann and Wölfel 1997). The dominating substrates of the Mulde riverbed and banks are alluvial sand and gravel, which is covered by sandy loam in the floodplains (Puhlmann and Rast 1997). Semiaquatic Mulde areas are characterised by annual vegetation communities dominated by ruderal plants. On higher slopes, which are flooded only at mid-range high-water levels and enriched with nutrients, there are nitrophilous communities of tall forbs (Warthemann and Wölfel 1997). The bordering floodplain landscape is a patchwork of oxbow lakes and grassland crossed by flood channels as well as hardwood alluvial forests and (to a small extent) arable land. Watersport use is limited to only a couple of days of the year (Reichhoff and Refior 1997).

By the early 1990s, the Mulde was one of the most polluted European rivers due to mining and industrial and urban activity (Reichhoff and Refior 1997; Klemm et al. 2005). Between 1990 and 2000, its biological quality classification changed from "excessively" to "moderately" polluted, a change mainly caused by the reduction of waste water discharge from chemical industries and the inauguration of the Bitterfeld/Wolfen sewage plant (LAWA 1991, 2002). Nevertheless, floodplain sediments are highly polluted with organic and inorganic compounds (Bräuer and Herzog 1997; Schulz-Zunkel et al. 2017). Sediment loss in the riverbed is another severe problem of the Mulde. Nearly all sediments from upstream get caught in the water reservoir at Muldenstein. Additionally, the reinforcement of cut banks-as it was done in the study area in the 1970s and 1980s (Reichhoff and Refior 1997) - contributes to riverbed deepening. This phenomenon decreases the average water surface levels and 
Fig. 1 Location of the project area in Germany (inlet) and arrangement of study sites along the Mulde river



increases floodplain dryness. The removal of river embankments to initiate erosion processes can play an important role in attenuating this degradation (Puhlmann and Rast 1997).

\section{Site types and treatments}

Samples were taken from two site types, namely 'natural' and 'managed'. We installed 12 transects with five pitfall traps for each transect per (Table 1) site type. Within site type we distinguished between slip-off slopes and cut banks with six transects each. This resulted in six replications (30 pitfall traps) for site types 'natural/slip-off slope', 'natural/ cut-off bank', 'managed/slip-off slope' and 'managed/cutoff bank'. The natural site type-lying near the core zone of the biosphere reserve-comprised a wide gravel bank and more downstream a cut bank, both sparsley overgrown with vegetation. Natural dynamic sedimentation and erosion processes characterised these sites. On managed sites cut banks were reinforced with blocks of stones and densely overgrown with grasses, herbs and shrubs. Slip-off slopes of 
managed sites were not stabilised but also characterised by relatively stable conditions due to the lack of sediments from cut banks. Compared to the natural gravel bank unvegetated areas were very small.

\section{Carabid sampling and species determination}

Carabids were sampled using pitfall traps ( $200 \mathrm{ml}$ volume, $7 \mathrm{~cm}$ top diameter) filled with a solution of $10 \%$ acetic acid and a splash of liquid detergent. Traps were placed along vertical transects (five traps per transect) at a distance between 0.5 and $1 \mathrm{~m}$ in height but at a maximum horizontal distance of $10 \mathrm{~m}$. Traps were exposed during two sampling times for two weeks in the spring and autumn 2016 (17.05.2016-31.05.2016, 31.05.2016-14.06.2016, 07.09.2016-20.09.2016 and 20.09.2016-05.10.2016) and spring 2017 (10.05.2017-24.05.2017 and 24.05.2017-08.06.2017).

Carabid individuals were determined using the identification key of Müller-Motzfeld (2006). Endangerment data were taken from the Red List of Germany (Schmidt et al. 2016) and Saxony-Anhalt (Schnitter and Trost 2004). To assess whether a species is a regional habitat specialist for the Middle Elbe floodplain, we referred to Schnitter et al. (2001). Both endangered species and regional habitat specialists were defined as species of conservation concern for subsequent analyses. This means that a species was given conservation importance if it was on the Red List of Germany, the Red List of Saxony-Anhalt or if it is considered a regional habitat specialist. If more than one was the case, the species was only counted once. For functional analyses, we assigned the following traits: annual activity time, body size, dispersal ability, eye size, food specialisation, hibernation mode and trophic level (Table 2). These features are meaningful traits for functional analyses (Klaiber et al. 2017; Moretti et al. 2017). Body size responds to environmental stress and refers to the amount and composition of resources used in a community. Food specialisation and trophic level correspond to the position in the food web, while eye size reflects prey as well as predator recognition. This phenomenon in turn determines the quality of resources that influences species fitness. Dispersal ability refers to species potential to access new habitats and resources and to escape adverse environmental conditions. Finally, annual activity time and hibernation mode reflect the possibility of co-occurrences among species and the ability to cope with unfavourable environmental conditions with a resting stage (Rothenbücher and Schaefer 2006; Lambeets et al. 2008a; Gerisch et al. 2012a; Moretti et al. 2017).

\section{Environmental variables}

Besides site type (slip-off slope, cut bank) and treatment (natural, managed) as categorical variables we measured two further environmental variables to characterise our transects (Table 1). In a $1 \times 1 \mathrm{~m}$ square around each pitfall trap, vegetation cover [\%] was recorded in 2016 and 2017 to subsequently calculate mean values. Distance to river was recorded on an ordinal scale and refers to the rank order of the pitfall trap in a line transect, i.e., 1 is the trap closest to the water side and 5 is the trap farthest away from the water.

\section{Data analysis}

For all analyses (with the exception of the habitat models), one sample unit included the pooled data from all five pitfall traps per transect. For subsequent comparisons, we calculated number of species, number of individuals and

Table 1 Site types and treatments used in this study

\begin{tabular}{lll}
\hline Site type/treatment & Vegetation cover $\%$ & Distance to river \\
\hline $\begin{array}{l}\text { Nature slip-off slope } \\
\text { Managed slip-off slope }\end{array}$ & 1 sqm plot around a trap & Number of the pitfall trap, 1 (close the water) to 5 (far away from water) \\
$\begin{array}{l}\text { Nature cut bank } \\
\text { Managed cut bank }\end{array}$ & \\
\hline
\end{tabular}

Table 2 Trait data taken for calculating functional diversity of carabid beetles

\begin{tabular}{lll}
\hline Trait & Categories & References \\
\hline Annual activity time & Number of active months & Klaiber et al. (2017) \\
Body size & mm & Klaiber et al. (2017) \\
Dispersal ability & brachypter, macropter, dimorphic & Homburg et al. (2014) \\
Eye size & $<10 \%, 10-25 \%,>25-50 \%$ & Homburg et al. (2014) \\
Food specialisation & Collembola, Gastropoda, Isopoda, no & Homburg et al. (2014) \\
Hibernation mode & Larva, Larva/Imago, Imago & Klaiber et al. (2017) \\
Trophic level & Herbivore, Omnivore, Predator & Homburg et al. (2014) \\
\hline
\end{tabular}


Simpson diversity per sample unit as measures for alphadiversity. To evaluate the conservation value of our study sites, we calculated the percentage of species of conservation concern per site. Additionally, based on mentioned ground beetles traits (Table 2) we calculated functional dispersion (FDis), functional evenness (FEve) and functional divergence (FDiv) to reflect functional diversity (Villéger et al. 2008; Laliberté and Legendre 2010) using R library FD (Laliberté et al. 2015). We interpreted FDis as a measure for functional diversity, because it is an index of functional richness, which considers relative species abundances by estimating their dispersion in a multidimensional trait space. FEve combines both the evenness of trait distribution and the evenness of species relative abundances. The index is 1 if all species show an equal abundance and all the traits are evenly distributed in the trait space; it declines towards 0 with increasing unevenness in either factor. Finally, FDiv expresses the distance of the most abundant species from the assemblage centroid in the trait space. FDiv is high when the most abundant species show extreme trait values and can be interpreted as a measure of variance (Laliberté and Legendre 2010). Comparisons in number of species, number of individuals, amount of species of conservation concern, Simpson diversity and functional diversity indices between treatments 'managed' and 'natural' were performed using generalised linear models (GLMs) and subsequent analysis of variance (ANOVA) based on chi-squared statistics ( $R$ library car; Fox and Weisberg 2011). We referred to a quasiPoisson distribution for count data (number of species and individuals) and a Gaussian distribution for percentages and indices (amount of species of conservation concern, Simpson diversity and functional diversity).

To test whether carabid beetle species composition was related to treatment and site type, we ran nonmetric multidimensional scaling (NMDS) analyses using R library vegan (Oksanen et al. 2019) and a permutational multivariate ANOVA (MANOVA; $r$ function adonis) with 10,000 permutations. Species with less than ten individuals at a site were regarded as accidental species and were omitted from analyses. Deleting rare species is a useful way to reduce the statistical noise in the data set without losing much information (McCune and Grace 2002; Leyer and Wesche 2007). The abundances of 46 species were square-root transformed before being subjected to NMDS. We used the Bray-Curtis dissimilarity as a distance measure and a maximum of 100 random starts to identify the best stress value for threedimensional models.

The fidelity and specificity of species within treatments 'natural' and 'managed' was explored using Indicator Value (IndVal) analysis (Dufrêne and Legendre 1997; Legendre and Legendre 1998) in R library labdsv (Roberts 2016). This approach calculates indicator values that range from 0 (no indication) to 100 (perfect indication). The latter value means that all individuals of a species are found in a single group (specificity), and, additionally, that the species occurs in all the sites of that group (fidelity). The statistical significance of the indicator values was tested using a Monte-Carlo randomisation procedure (10,000 runs) at a level of $\mathrm{P}<0.01$.

Finally, we calculated habitat models for the most abundant species (Amara luncicollis, Demetrias monostigma, Harpalus affinis, Harpalus latus, Lionychus quadrillum, Microlestes minutulus, Philorhizus sigma and Poecilus versicolor) and the identified indicator species (Abax parallelepipedus, Amara convexior, Elaphropus diabrachys, Harpalus tardus and Poecilus cupreus) using Poisson GLMs. We treated the results of every single trap as one sampling unit. Predictor variables in all models were site type (cut bank or slip-off slope), treatment (natural or managed), distance to river and herbal layer coverage. Since overdispersion was detected in all models by using 'dispersiontest' in R library aer (Kleiber and Zeileis 2018), we corrected the standard errors using quasi-Poisson GLMs. Model performance was verified visually using diagnostic plots following the protocol by Zuur et al. (2009). The significance of predictor variables were tested using subsequent ANOVA based on chisquared statistics (R library car, Fox and Weisberg 2011).

All statistical analyses were performed using the R software environment (version 3.4.4, R Core Team 2018).

\section{Results}

In total, 111 carabid beetle species from 36,932 individuals were identified (Appendix 1). The most abundant species by far was L. quadrillum (33,987 individuals). M. minutulus (630) and $P$. versicolor (449) were also frequent, followed by D. monostigma (163), H. latus (160), H. affinis (120), Amara lunicollis (117) and P. sigma (111). During the study, 24 species of conservation concern were collected (Appendix 2). Of them, Perileptus areolatus was considered regionally extinct. It is endangered in Germany, while Dyschirius intermedius is critically endangered in Saxony-Anhalt. Amara quenseli silvicola and Abax carinatus carinatus are endangered, while Badister sodalis, Blethisa multipunctata and Brachinus explodens are considered vulnerable.

For cut banks, natural sites harboured significantly more individuals ( $\varnothing 332$ vs 180 individuals; $\mathrm{t}=2.3, \mathrm{P}=0.04$; Fig. 2). Additionally, Simpson diversity ( $\varnothing 0.85$ vs 0.76 ; $\mathrm{t}=4.4, \mathrm{P}=0.001)$ and functional dispersion ( 00.32 vs 0.25$)$ $\mathrm{t}=5.6, \mathrm{P}<0.001$; Fig. 3) were significantly higher for these sites, but there were no significant differences for number of species, amount of species of conservation concern, functional evenness or functional divergence. For slip-off slopes, the number of species was significantly higher in managed sites ( boured significantly more individuals ( 

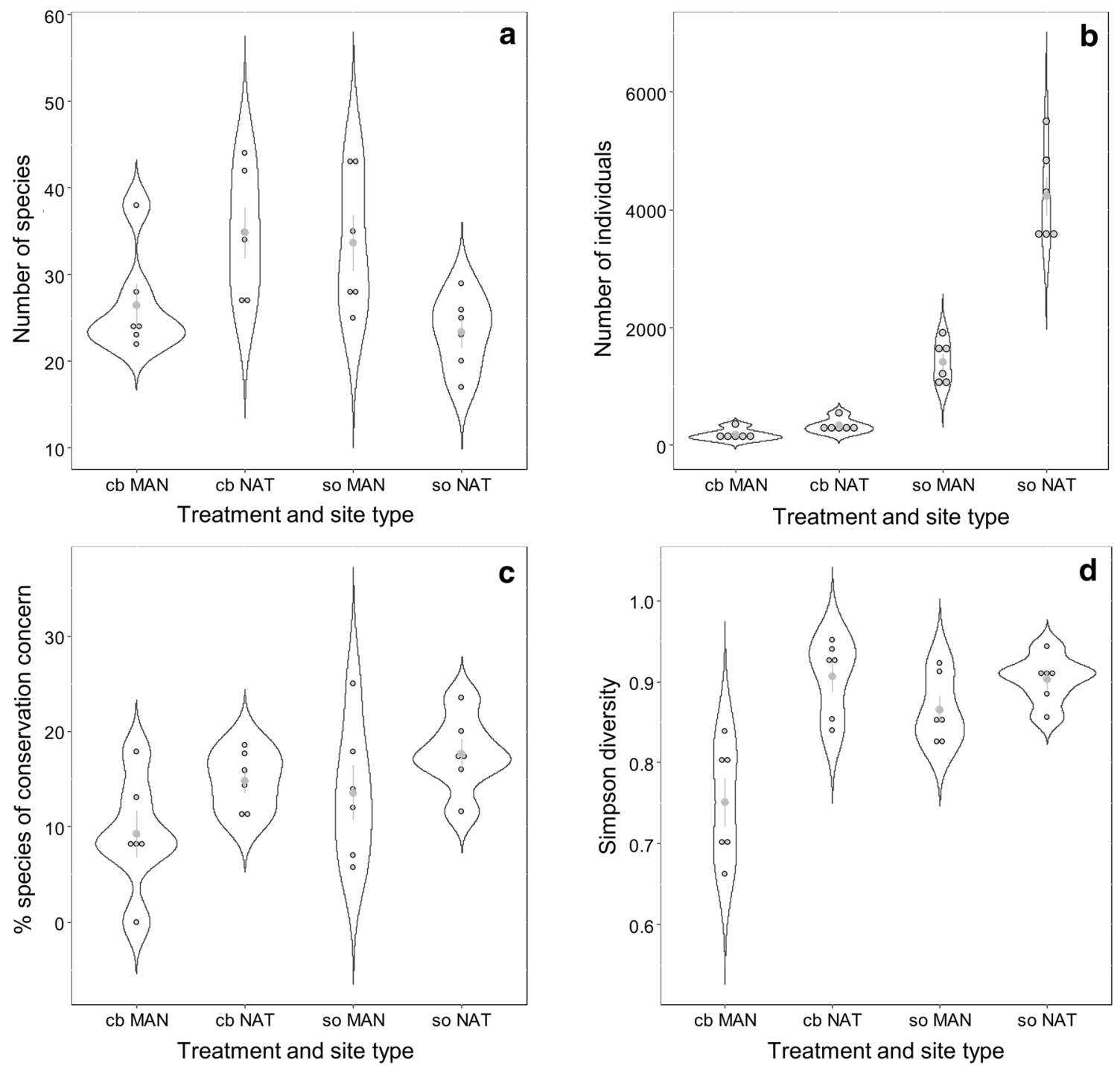

Fig. 2 Differences between treatments 'nature' (NAT) and 'manage' (MAN) for site types 'cut bank' (cb) and 'slip-off slope' (so) were significant for species numbers (slip-off slopes: $\mathrm{t}=2.9, \mathrm{P}=0.02$, analysis of deviance), number of individuals (slip-off slopes and cut

$\mathrm{t}=7.9, \mathrm{P}<0.001)$. Differences in all functional diversity indices were significant, with higher functional dispersion (Ø 0.32 vs $0.27 ; \mathrm{t}=3.1, \mathrm{P}=0.01)$ and functional evenness $(\varnothing 0.80$ vs $0.70 ; \mathrm{t}=3.0, \mathrm{P}=0.01)$ in natural sites and lower functional divergence in managed ones $(\varnothing 0.87$ vs 0.86 ; $\mathrm{t}=3.1, \mathrm{P}=0.01$; Fig. 3).

Site type $\left(\mathrm{F}=25.8, \mathrm{P}<0.001, \mathrm{R}^{2}=0.48\right.$, permutational MANOVA) and treatment $\left(\mathrm{F}=7.0, \mathrm{P}=0.001, \mathrm{R}^{2}=0.13\right.$, permutational MANOVA) significantly affected species composition (Fig. 4). Consequently, NMDS showed groupings-albeit rudimentary-among cut banks and slip-off slopes, and to a lesser extent among natural and managed sites ( 3 dimensions, stress $=0.12$ ). Indicator species analysis

banks: $\mathrm{t}=7.9, \mathrm{P}<0.001$ and $\mathrm{t}=2.3, \mathrm{P}=0.04)$ and Simpson diversity (cut banks: $\mathrm{t}=4.4, \mathrm{P}=0.001$ ). Violin plots show values per site (open circles), mean (grey circle) and standard error of the mean (grey lines). Bulges of violins indicate aggregation of same values

revealed three species characteristic for nature sites $(L$. quadrillum: indicator value $[\mathrm{IV}]=0.78, \mathrm{P}=0.02 ; \mathrm{H}$. latus: $\mathrm{IV}=0.78, \mathrm{P}=0.006 ;$ E. diabrachys: $\mathrm{IV}=0.46, \mathrm{P}=0.04)$ and seven carabids typical for managed ones (A. convexior: $\mathrm{IV}=0.87, \mathrm{P}=0.001 ;$ P. versicolor $: \mathrm{IV}=0.79, \mathrm{P}=0.001$; H. tardus: $\mathrm{IV}=0.73, \mathrm{P}=0.008 ; M$. minutulus: $\mathrm{IV}=0.72$, $\mathrm{P}=0.03 ;$ A. parallelepipedus: $\mathrm{IV}=0.71, \mathrm{P}=0.001 ;$ A. luncicollis: $\mathrm{IV}=0.70, \mathrm{P}=0.03 ;$. . cupreus: $\mathrm{IV}=0.68, \mathrm{P}=0.005)$.

Habitat models indicated specific preferences for most abundant and indicator species (summary in Fig. 5; for detailed results of all habitat models, see Appendix 3). Herbal layer coverage and amount of open soil did not significantly affect species distribution-apart from A. convexior 
Fig. 3 Differences between treatments 'nature' (NAT) and 'manage' (MAN) for site types 'cut bank' (cb) and 'slip-off slope' (so) were significant for functional dispersion (slip-off slopes and cut banks: $\mathrm{t}=3.1, \mathrm{P}=0.01$ and $\mathrm{t}=5.6, \mathrm{P}<0.001$, analysis of deviance), functional evenness (slip-off slopes: $\mathrm{t}=3.0, \mathrm{P}=0.01$ ) and functional divergence (slip-off slopes: $\mathrm{t}=3.1, \mathrm{P}=0.01$ ). Violin plots show values per site (open circles), mean (grey circle) and standard error of the mean (grey lines). Bulges of violins indicate aggregation of same values

that preferred mosaics of open soil and herbal layer-but distance to river, site type and treatment were significant: L. quadrillum was bound to the river near natural slip-off slopes, whereas E. diabrachys and H. latus occurred on both site types of natural river sections. While the latter species exhibited no preferences, $E$. diabrachys was related to riverbanks near the waterline. A. parallelepipedus, A. convexior, $H$. affinis, $H$. tardus and $P$. cupreus were bound to managed sites with preferences for slip-off slopes (A. convexior), cut banks (H. affinis and $H$. tardus) or both (A. parallelepipe$d u s$ ), while distance to river had no effect. A. lunicollis, $D$. monostigma and $P$. versicolor preferably occurred in slip-off slopes independent of treatment; this feature was the same for M. minutulus at cut banks.

\section{Discussion}

The 'Wilde Mulde' revitalisation project is unique for a lowland river ecosystem because it combines riparian habitat restoration at the habitat level and large-scale reconnection with old river branches and riparian forests at the landscape level. We aimed to assess the status quo in the objective area before restoration by comparing natural and managed river habitats. Our results indicated that differences between both sites were less obvious than expected; carabid beetle taxonomic and functional diversity was not per se higher in natural sites. Consistently, natural sites had higher numbers of individuals and functional diversity in both site types. Therefore, our first expectation was only partially confirmed. Our data also indicated that study site location in either cut banks or slip-off slopes had much stronger effects. In contrast, Simpson diversity and functional evenness was higher in natural sites of cut banks, while in slip-off slopes, species number was higher in managed sites. These results are surprising, because number of carabid species normally decreases with increasing human impact at managed riverbanks (Boscaini et al. 2000; Andersen and Hanssen 2005; Cavaillé et al. 2013), a phenomenon that leads to impoverished species assemblages with low numbers of stenotopic species (Bonn et al. 2002). Apart from this, the higher number of species could be explained by the fact that more eurytopic species can be found in managed sites whereas natural sites are more appropriate for stenotopic species. However, apart from species numbers, Simpson and functional
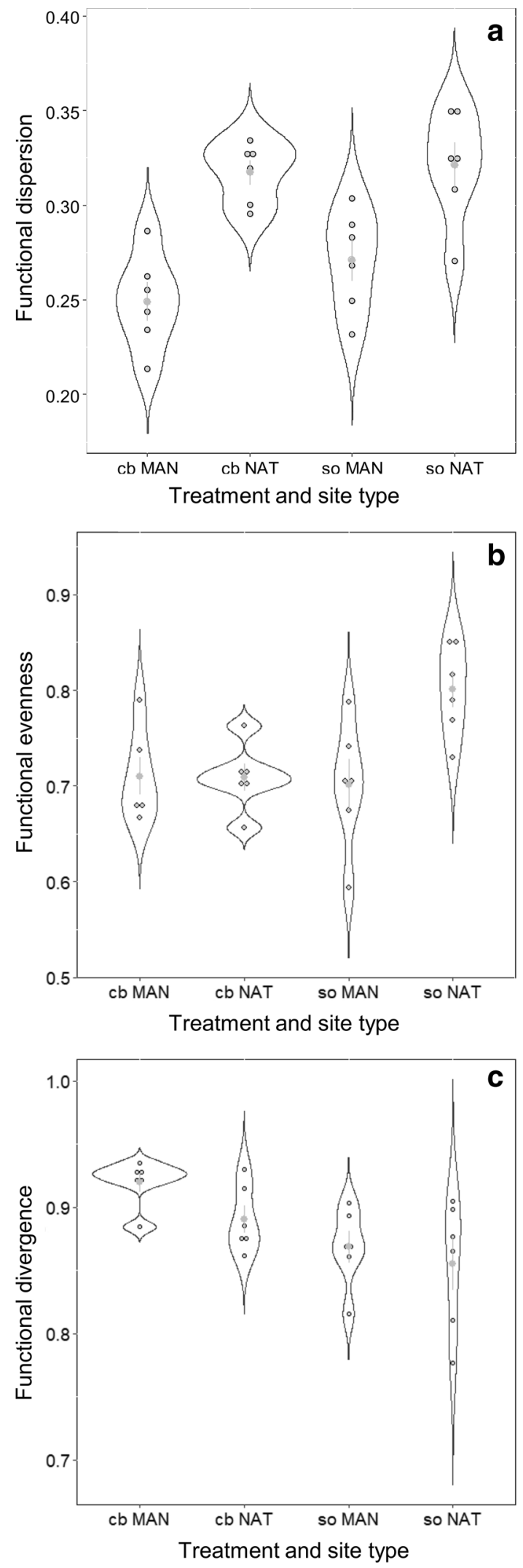


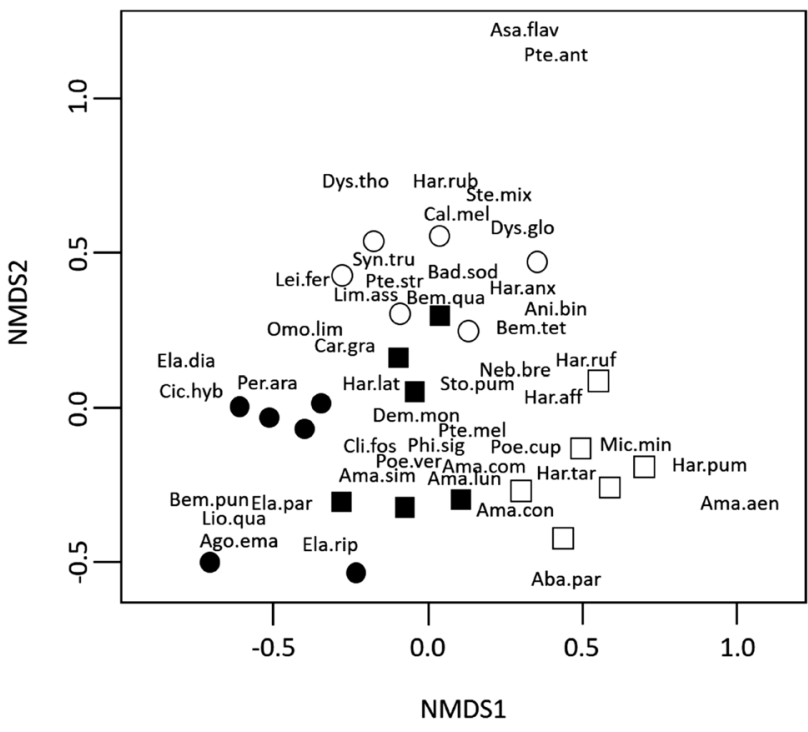

Fig. 4 Visualisation of NMDS analysis (3 dimensions, Bray-Curtis distance, stress $=0.12$, two convergent solutions after 20 tries) on square-root transformed carabid species abundances (46 species) of slip-off slopes (nature $=$ filled circle, managed $=$ filled square) and cut banks (nature $=$ open circle, managed $=$ open square). Species abbreviations (significant indicator species for treatments in

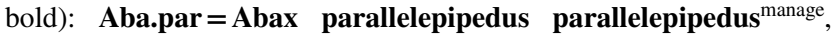
Ago.ema=Agonum emarginatum, Ama.aen=Amara aenea, Ama. com =Amara communis, Ama.con = Amara convexior ${ }^{\text {manage }}$, Ama. lun=Amara lunicollis ${ }^{\text {manage }}$, Ama.sim =Amara similata, Ani. bin=Anisodactylus binotatus, Asa.fla=Asaphidion flavipes, Bad. sod=Badister sodalis, Bem.pun =Bembidion punctulatum, Bem. qua $=$ Bembidion quadrimaculatum, Bem.tet $=$ Bembidion tetracolum, Cal.mel=Calathus melanocephalus, Car.gra=Carabus granulatus granulatus, Cic.hyb=Cicindela hybrida, Cli.fos =Clivina fossor, Dem.mon=Demetrias monostigma, Dys.glo=Dyschirius globosus, Dys.tho $=$ Dyschirius thoracicus, Ela.dia = Elaphropus diabrachy$\mathbf{s}^{\text {nature }}$, Ela.par $=$ Elaphropus parvulus, Ela.rip=Elaphrus riparius, Har.aff $=$ Harpalus affinis, Har.anx = Harpalus anxius, Har.lat = Harpalus latus $^{\text {nature }}$, Har.pum $=$ Harpalus pumilus, Har.rub $=$ Harpalus rubripes, Har.ruf = Harpalus rufipes, Har.tar = Harpalus tardusmanage, Lei.fer $=$ Leistus ferrugineus, Lim.ass =Limodromus assimi lis, Lio.qua $=$ Lionychus quadrillum $^{\text {nature }}$, Mic.min $=$ Microlestes minutulus $^{\text {manage }}$, Neb.bre $=$ Nebria brevicollis, Omo.lim $=$ Omophron limbatum, Per.are = Perileptus areolatus, Phi.sig = Philorhizus sigma, Poe.cup $=$ Poecilus cupreus $^{\text {manage }}$, Poe.ver $=$ Poecilus versicolormanage, Pte.ant $=$ Pterostichus anthracinus, Pte.mel=Pterostichus melanarius, Pte.str =Pterostichus strenuus, Ste.mix =Stenolophus mixtus, Sto.pum $=$ Stomis pumicatus, Syn.tru=Syntomus truncatellus

diversity were higher at natural sites, a finding that may be explained by a higher habitat diversity, for example, due to river dynamics (Paillex et al. 2017; Lorenz et al. 2018). This phenomenon creates a mosaic of microhabitats (e.g., different substrate grain sizes, open sand or gravel patches, low and dense vegetated sites) that promote taxonomic and functional diverse carabid beetle assemblages (Jähnig et al. 2009; Januschke and Verdonschot 2016; Bednarska et al. 2018). Additionally, the higher number of individuals in natural sites is consistent with previous findings; carabids have a great capacity to increase their abundance in response to habitat dynamics (Bednarska et al. 2018).

Our second hypothesis addressed a higher importance for conservation in natural sites measured by a higher percentage of species of conservation concern. Both natural and managed sites harboured the same percentage of species of conservation concern, and there were no significant differences between location in cut bank or slip-off slope. The Mulde River generally harbours species of conservation concern, and the occurrence of Bembidion punctulatum, P. areolatus and D. intermedius should be highlighted. In particular, $P$. areolatus is a riparian specialist bound to river dynamics and flooding (Andersen and Hanssen 2005). It was considered regionally extinct and was only recently rediscovered in the study area (Thurow 2016). Furthermore, B. punctulatum is a riparian specialist indicative of open and less-vegetated natural riverbanks (Schnitter et al. 2001). Although not recorded during this study, Thurow (2016) also recorded the riparian specialists Bembidion decorum, Bembidion fluviatile and Elaphrus aureus by pitfall trapping and hand sampling in the study area. In light of future restoration plans, these results are very promising because it can be assumed that preconditions-for example, a local species pool of riparian habitat specialists-that are mandatory for a successful restoration are present. Future restoration can create more beneficial microhabitats even compared to natural sites, and these places can regularly be colonised rapidly by typical riparian carabids with high dispersal abilities (Günther and Assmann 2005; Bates et al. 2006; Bednarska et al. 2018). These beneficial microhabitats should comprise open pioneer habitats such as bare sand or gravel patches subjected to river dynamics (Sadler et al. 2004; Van Looy et al. 2005; Paillex et al. 2017; Lorenz et al. 2018). Increased river dynamics and flooding due to river widening can promote faster positive responses from riparian habitat specialists (Jähnig et al. 2009; Januschke et al. 2014; Januschke and Verdonschot 2016). While restoration will create appropriate conditions at the habitat level, the surrounding landscape composition and its permeability will significantly affect successful establishment of specialist populations (Stockan et al. 2014). This phenomenon is because restored sites are often islands in a vastly altered landscape exposed to anthropogenic use (Lorenz and Feld 2013).

Our third hypothesis was confirmed, because both natural and managed sites harboured specific species assemblages with characteristic indicator species. Lorenz et al. (2018) showed that carabid species turnover can reach up to $80 \%$ along naturality gradients. This phenomenon results from carabid beetles' often quick response to habitat modifications in river ecosystems (Günther and Assmann 2005), namely due to their strong flight ability (Lambeets et al. 2008a). In particular, heterogenous habitats harbour diverse and distinct carabid assemblages where riparian habitat specialists—and 
Fig. 5 Habitat preferences for most abundant species and indicator species (quasipoisson GLMs with predictors 'site type' (slip-off slope / cut bank), 'treatment' (nature/manage), 'distance from river', 'coverage of herbal layer'). Only significant responses with $\mathrm{P}<0.05$ are displayed. For detailed results of all habitat models see Appendix 3



at the same time indicator species for successful restoration (such as E. diabrachys and L. quadrillum)-prefer gravel banks with flooding impact, hygrophiles (e.g., P. cupreus and $P$. versicolor) inhabit loamy river banks with vegetation cover and xerophiles (e.g., A. lunicollis, H. latus and H. tar$d u s$ ) occur on sandy banks that are rarely flooded (Lambeets et al. 2008b).

\section{Conclusions}

In general, our results show that carabid beetles are very good indicators for comparing human impact and naturalness in river ecosystems. This is due to the strong habitat preferences, especially of stenotopic riparian specialists, and fast and distinctive spatial turnover in species assemblages with associated indicator species. Setting the scene for future restoration, it is necessary to define specified targets and to adjust restoration activities and species action plans. Our results indicate high ecological development potentials for the Mulde River and principles for restoration:

(1) There is a local species pool of riparian habitat specialists with B. decorum, B. fluviatile, B. punctulatum, D. intermedius, E. aureus and P. areolatus that even occur at managed sites (see Appendices 1 and 2). It can be assumed that future restoration will foster population increases as well as a wider distribution of these riparian habitat specialists.
(2) Species richness was not per se higher in natural river habitats, and there were no differences regarding the abundance of species of conservation concern at any sites. These data might indicate favourable basic conditions even at managed sites. However, taxonomic (in terms of Simpson diversity) and functional diversity were lower in managed sites, findings that indicate natural sites present appropriate references for measuring positive restoration effects. Finally, the presence of slip-off slopes - which are a main sign of natural riparian zones - can support the development of population growth as more individuals were found here.

(3) Restoration can cause different results depending on the location of riparian sites. Both slip-off slopes and cut off banks had distinct biodiversity patterns and species assemblages. For example, A. lunicollis, D. monostigma and $P$. versicolor were associated with slip-off slopes, while M. minutulus was related to cut banks. Keeping these differences in mind during restoration action should increase local diversity by creating a habitat mosaic and different habitat conditions for a broad spectrum of carabid species. Additionally, subsequent monitoring should consider restoration results in slip-off slopes and cut off banks separately to cope with these differences.

(4) A pronounced species turnover in response to restoration can be expected. This effect will be associated with an increase in indicator species typical for nature sites, such as E. diabrachys, H. latus and L. quadrillum. At 
the same time, species indicative for managed sites, including A. parallelepipedus, A. convexior, H. affinis and $H$. tardus, are predicted to disappear.

Acknowledgements Open Access funding provided by Projekt DEAL. We thank Alexander Drexler, Carolin Lenski and Julia Henschel for supporting the field work and the sorting of pitfall trap catches and Ingo Brunk for identifying carabid beetles. Additionally, we thank Peer Schnitter from the Landesamt für Umweltschutz Sachsen-Anhalt and the employees from the Environmental Agencies of the districts Anhalt-Bitterfeld and Dessau-Rosslau for giving us permission to enter the study sites and collect carabid beetles. Our special thanks go to Holger Gabriel from the Biosphere Reserve Middle Elbe for sharing his expertise to avoid conflicts with the regional breeding bird fauna. We thank all participants of the project "Wilde Mulde" for their continuous support and conceptual input. Finally, we thank two reviewers for valuable comments on our manuscript. This project was funded by the Bundesministerium für Bildung und Forschung (BMBF) and the Bundesamt für Naturschutz (BfN), with grants from the Bundesministerium für Umwelt, Naturschutz, Bau und Reaktorsicherheit (BMUB). This work is part of the research initiative for sustainable development (FONA, www.fona.de), WilMu - project: No. 01LC1322D.

Author contributions CS and FD conceived and designed the research; CS performed the field work; SB analysed the data; SB, CS, FD wrote and edited the manuscript.

\section{Compliance with ethical standards}

Conflict of interest The authors declare no conflict of interest.
Ethical approval The authors obtained all appropriate ethics and other approvals for the research. All necessary permits were obtained to perform carabid beetle samplings. No human participants were involved in the work.

Informed consent All authors consent to the submission of this manuscript.

Open Access This article is licensed under a Creative Commons Attribution 4.0 International License, which permits use, sharing, adaptation, distribution and reproduction in any medium or format, as long as you give appropriate credit to the original author(s) and the source, provide a link to the Creative Commons licence, and indicate if changes were made. The images or other third party material in this article are included in the article's Creative Commons licence, unless indicated otherwise in a credit line to the material. If material is not included in the article's Creative Commons licence and your intended use is not permitted by statutory regulation or exceeds the permitted use, you will need to obtain permission directly from the copyright holder. To view a copy of this licence, visit http://creativecommons.org/licenses/by/4.0/.

\section{Appendix 1}

See Table 3 . 
Table 3 Species list and individual sums

\begin{tabular}{|c|c|c|c|c|c|}
\hline \multirow[t]{2}{*}{ Species } & \multicolumn{2}{|l|}{ Nature } & \multicolumn{2}{|l|}{ Manage } & \multirow[t]{2}{*}{ Sum } \\
\hline & Cut bank & $\overline{\text { Slip-off slope }}$ & Cut bank & Slip-off slope & \\
\hline Abax carinatus carinatus & 1 & 0 & 0 & 0 & 1 \\
\hline Abax parallelepipedus parallelepipedus & 0 & 1 & 16 & 4 & 21 \\
\hline Abax parallelus parallelus & 0 & 1 & 0 & 0 & 1 \\
\hline Acupalpus exiguus & 0 & 0 & 3 & 0 & 3 \\
\hline Acupalpus flavicollis & 1 & 0 & 3 & 1 & 5 \\
\hline Acupalpus meridianus & 2 & 0 & 1 & 0 & 3 \\
\hline Agonum emarginatum & 0 & 6 & 1 & 4 & 11 \\
\hline Agonum micans & 0 & 0 & 1 & 0 & 1 \\
\hline Agonum sexpunctatum & 0 & 0 & 0 & 1 & 1 \\
\hline Amara aenea & 2 & 0 & 73 & 0 & 75 \\
\hline Amara communis & 15 & 2 & 9 & 25 & 51 \\
\hline Amara convexior & 2 & 7 & 31 & 27 & 67 \\
\hline Amara eurynota & 0 & 2 & 0 & 2 & 4 \\
\hline Amara familiaris & 5 & 1 & 2 & 2 & 10 \\
\hline Amara fulva & 1 & 0 & 0 & 1 & 2 \\
\hline Amara lunicollis & 25 & 10 & 34 & 48 & 117 \\
\hline Amara ovata & 0 & 2 & 0 & 2 & 4 \\
\hline Amara plebeja & 0 & 2 & 0 & 1 & 3 \\
\hline Amara quenseli quenseli & 1 & 0 & 0 & 0 & 1 \\
\hline Amara similata & 3 & 5 & 4 & 12 & 24 \\
\hline Anchomenus dorsalis & 0 & 1 & 0 & 0 & 1 \\
\hline Anisodactylus binotatus & 4 & 1 & 5 & 3 & 13 \\
\hline Anthracus consputus & 0 & 0 & 1 & 0 & 1 \\
\hline Asaphidion flavipes & 4 & 0 & 0 & 0 & 4 \\
\hline Asaphidion pallipes & 1 & 0 & 0 & 0 & 1 \\
\hline Badister bullatus & 5 & 2 & 0 & 1 & 8 \\
\hline Badister lacertosus & 0 & 2 & 0 & 0 & 2 \\
\hline Badister sodalis & 18 & 1 & 2 & 1 & 22 \\
\hline Bembidion biguttatum & 0 & 0 & 0 & 1 & 1 \\
\hline Bembidion doris & 2 & 0 & 0 & 0 & 2 \\
\hline Bembidion femoratum & 0 & 1 & 0 & 0 & 1 \\
\hline Bembidion gilvipes & 0 & 0 & 1 & 3 & 4 \\
\hline Bembidion guttula & 2 & 0 & 0 & 1 & 3 \\
\hline Bembidion lampros & 0 & 0 & 1 & 1 & 2 \\
\hline Bembidion lunulatum & 0 & 0 & 1 & 0 & 1 \\
\hline Bembidion modestum & 0 & 3 & 0 & 1 & 4 \\
\hline Bembidion properans & 0 & 0 & 0 & 1 & 1 \\
\hline Bembidion punctulatum & 4 & 15 & 0 & 30 & 49 \\
\hline Bembidion pygmaeum & 3 & 0 & 0 & 1 & 4 \\
\hline Bembidion quadrimaculatum & 3 & 1 & 1 & 5 & 10 \\
\hline Bembidion tetracolum & 3 & 0 & 1 & 14 & 18 \\
\hline Blethisa multipunctata & 0 & 0 & 1 & 0 & 1 \\
\hline Calathus melanocephalus & 7 & 0 & 0 & 5 & 12 \\
\hline Carabus granulatus granulatus & 3 & 4 & 1 & 12 & 20 \\
\hline Carabus nemoralis & 1 & 4 & 0 & 2 & 7 \\
\hline Chlaenius nigricornis & 2 & 0 & 1 & 2 & 5 \\
\hline Cicindela hybrida & 7 & 5 & 0 & 2 & 14 \\
\hline Clivina collaris & 1 & 0 & 0 & 0 & 1 \\
\hline Clivina fossor & 5 & 6 & 4 & 20 & 35 \\
\hline
\end{tabular}


Table 3 (continued)

\begin{tabular}{|c|c|c|c|c|c|}
\hline \multirow[t]{2}{*}{ Species } & \multicolumn{2}{|l|}{ Nature } & \multicolumn{2}{|l|}{ Manage } & \multirow[t]{2}{*}{ Sum } \\
\hline & Cut bank & Slip-off slope & Cut bank & Slip-off slope & \\
\hline Cychrus caraboides & 1 & 1 & 0 & 0 & 2 \\
\hline Demetrias imperialis & 1 & 0 & 0 & 1 & 2 \\
\hline Demetrias monostigma & 39 & 20 & 10 & 94 & 163 \\
\hline Diachromus germanus & 0 & 0 & 0 & 2 & 2 \\
\hline Dyschirius globosus & 18 & 1 & 4 & 0 & 23 \\
\hline Dyschirius intermedius & 0 & 0 & 1 & 0 & 1 \\
\hline Dyschirius thoracicus & 9 & 0 & 0 & 2 & 11 \\
\hline Elaphropus diabrachys & 7 & 5 & 0 & 1 & 13 \\
\hline Elaphropus parvulus & 6 & 36 & 3 & 9 & 54 \\
\hline Elaphrus cupreus & 0 & 1 & 0 & 0 & 1 \\
\hline Elaphrus riparius & 0 & 1 & 1 & 15 & 17 \\
\hline Harpalus affinis & 41 & 8 & 65 & 6 & 120 \\
\hline Harpalus anxius & 2 & 1 & 5 & 0 & 8 \\
\hline Harpalus autumnalis & 0 & 0 & 1 & 0 & 1 \\
\hline Harpalus distinguendus & 1 & 1 & 1 & 0 & 3 \\
\hline Harpalus froelichii & 1 & 0 & 0 & 1 & 2 \\
\hline Harpalus latus & 100 & 24 & 21 & 15 & 160 \\
\hline Harpalus luteicornis & 2 & 0 & 0 & 1 & 3 \\
\hline Harpalus picipennis & 2 & 0 & 0 & 0 & 2 \\
\hline Harpalus pumilus & 1 & 0 & 7 & 0 & 8 \\
\hline Harpalus rubripes & 7 & 0 & 1 & 2 & 10 \\
\hline Harpalus rufipes & 6 & 0 & 16 & 3 & 25 \\
\hline Harpalus tardus & 4 & 1 & 27 & 8 & 40 \\
\hline Harpalus xanthopus & 1 & 0 & 2 & 2 & 5 \\
\hline Leistus ferrugineus & 10 & 3 & 0 & 5 & 18 \\
\hline Leistus rufomarginatus & 0 & 0 & 0 & 1 & 1 \\
\hline Licinus depressus & 0 & 0 & 0 & 1 & 1 \\
\hline Limodromus assimilis & 4 & 1 & 0 & 13 & 18 \\
\hline Lionychus quadrillum & 1283 & 25,086 & 10 & 7608 & 33,987 \\
\hline Loricera pilicornis & 1 & 0 & 3 & 2 & 6 \\
\hline Microlestes minutulus & 81 & 3 & 529 & 17 & 630 \\
\hline Nebria brevicollis & 6 & 3 & 9 & 8 & 26 \\
\hline Notiophilus aestuans & 0 & 1 & 0 & 3 & 4 \\
\hline Notiophilus biguttatus & 1 & 1 & 1 & 1 & 4 \\
\hline Notiophilus palustris & 2 & 0 & 0 & 0 & 2 \\
\hline Omophron limbatum & 16 & 4 & 0 & 6 & 26 \\
\hline Oodes helopioides & 1 & 0 & 0 & 1 & 2 \\
\hline Oxypselaphus obscurus & 3 & 1 & 2 & 2 & 8 \\
\hline Panagaeus bipustulatus & 1 & 1 & 0 & 3 & 5 \\
\hline Panagaeus cruxmajor & 2 & 1 & 0 & 1 & 4 \\
\hline Paradromius linearis & 0 & 0 & 1 & 0 & 1 \\
\hline Paranchus albipes & 0 & 0 & 3 & 4 & 7 \\
\hline Patrobus atrorufus & 0 & 0 & 1 & 0 & 1 \\
\hline Perileptus areolatus & 13 & 4 & 0 & 3 & 20 \\
\hline Philorhizus sigma & 35 & 7 & 17 & 52 & 111 \\
\hline Poecilus cupreus & 8 & 2 & 13 & 15 & 38 \\
\hline Poecilus versicolor & 58 & 35 & 86 & 270 & 449 \\
\hline Pterostichus anthracinus & 5 & 0 & 0 & 0 & 5 \\
\hline Pterostichus diligens & 0 & 0 & 0 & 1 & 1 \\
\hline
\end{tabular}


Table 3 (continued)

\begin{tabular}{|c|c|c|c|c|c|}
\hline \multirow[t]{2}{*}{ Species } & \multicolumn{2}{|l|}{ Nature } & \multicolumn{2}{|l|}{ Manage } & \multirow[t]{2}{*}{ Sum } \\
\hline & Cut bank & Slip-off slope & Cut bank & Slip-off slope & \\
\hline Pterostichus gracilis & 1 & 0 & 0 & 0 & 1 \\
\hline Pterostichus melanarius & 25 & 17 & 21 & 17 & 80 \\
\hline Pterostichus minor & 0 & 1 & 0 & 0 & 1 \\
\hline Pterostichus niger & 0 & 1 & 3 & 0 & 4 \\
\hline Pterostichus nigrita & 3 & 0 & 0 & 1 & 4 \\
\hline Pterostichus oblongopunctatus & 0 & 0 & 0 & 1 & 1 \\
\hline Pterostichus strenuиs & 24 & 6 & 2 & 41 & 73 \\
\hline Pterostichus vernalis & 3 & 0 & 1 & 1 & 5 \\
\hline Stenolophus mixtus & 1 & 0 & 0 & 3 & 4 \\
\hline Stomis pumicatus & 8 & 5 & 9 & 9 & 31 \\
\hline Syntomus truncatellus & 13 & 3 & 3 & 1 & 20 \\
\hline Synuchus vivalis & 0 & 0 & 1 & 0 & 1 \\
\hline Trechus quadristriatus & 1 & 3 & 0 & 0 & 4 \\
\hline Sum & 1991 & 25,374 & 1078 & 8489 & 36,932 \\
\hline
\end{tabular}

\section{Appendix 2}

See Table 4.
Table 4 Species of conservation concern: RL Ger= Red list Germany (Schmidt et al. 2016), RL S-A=Red List Saxony-Anhalt (Schnitter and Trost, 2004), habitat specialist $=$ regional assessment according to Schnitter et al. (2001)

\begin{tabular}{|c|c|c|c|}
\hline Species & RL Ger & RL S-A & $\begin{array}{l}\text { Habitat } \\
\text { special- } \\
\text { ist }\end{array}$ \\
\hline Abax carinatus carinatus & $\mathrm{V}$ & 2 & Yes \\
\hline Abax parallelus parallelus & & & Yes \\
\hline Acupalpus exiguus & & & Yes \\
\hline Amara quenseli silvicola & 3 & 2 & Yes \\
\hline Anthracus consputus & V & & \\
\hline Asaphidion pallipes & V & & \\
\hline Badister sodalis & & 3 & \\
\hline Bembidion doris & V & & \\
\hline Bembidion modestum & 3 & & Yes \\
\hline Bembidion punctulatum & & & Yes \\
\hline Bembidion pygmaeum & V & $\mathrm{R}$ & \\
\hline Blethisa multipunctata & 3 & 3 & Yes \\
\hline Brachinus explodens & V & 3 & \\
\hline Diachromus germanus & & $\mathrm{R}$ & \\
\hline Dyschirius intermedius & & 1 & Yes \\
\hline Harpalus autumnalis & 3 & & \\
\hline Harpalus picipennis & 3 & & \\
\hline Harpalus xanthopus & & $\mathrm{R}$ & \\
\hline Licinus depressus & $\mathrm{V}$ & & \\
\hline Lionychus quadrillum & & & Yes \\
\hline Notiophilus aestuans & V & & \\
\hline Omophron limbatum & V & & \\
\hline Perileptus areolatus & 2 & 0 & \\
\hline Pterostichus gracilis & $\mathrm{V}$ & & YES \\
\hline
\end{tabular}

Categories of endangerment: $\mathrm{R}=$ rare, $\mathrm{V}=$ near threatened, $3=$ vulnerable, $2=$ endangered, $1=$ critically endangered, $0=$ regionally Extinct 


\section{Appendix 3}

See Table 5 .

Table 5 Statistical results of quasipoisson GLMs on responses of most abundant and indicator species to predictors 'site type' (slip-off slope/cut bank), 'treatment' (nature/ manage), 'distance from river' and 'coverage of herbal layer'). Model for Poecilus cupreus did not fit due to low individual sums and was therefore excluded

\begin{tabular}{|c|c|c|c|c|c|}
\hline Species & Site type & Treatment & Distance & Vegetation & $\mathrm{R}^{2}$ \\
\hline Abax parallelepipedus & $\begin{array}{l}\chi^{2}=1.9 \\
P=0.17\end{array}$ & $\begin{array}{l}\chi^{2}=5.6 \\
P=0.02\end{array}$ & $\begin{array}{l}\chi^{2}=2.3 \\
P=0.68\end{array}$ & $\begin{array}{l}\chi^{2}=1.5 \\
P=0.23\end{array}$ & 30.1 \\
\hline Amara convexior & $\begin{array}{l}\chi^{2}=13.7 \\
P<0.001\end{array}$ & $\begin{array}{l}\chi^{2}=4.8 \\
P=0.03\end{array}$ & $\begin{array}{l}\chi^{2}=33.6 \\
P<0.001\end{array}$ & $\begin{array}{l}\chi^{2}=6.0 \\
P=0.01\end{array}$ & 50.7 \\
\hline Amara lunicollis & $\begin{array}{l}\chi^{2}=5.0 \\
P=0.02\end{array}$ & $\begin{array}{l}\chi^{2}=0.005 \\
P=0.95\end{array}$ & $\begin{array}{l}\chi^{2}=16.4 \\
P=0.002\end{array}$ & $\begin{array}{l}\chi^{2}=0.3 \\
P=0.58\end{array}$ & 36.8 \\
\hline Demetrias monostigma & $\begin{array}{l}\chi^{2}=7.8 \\
P=0.005\end{array}$ & $\begin{array}{l}\chi^{2}=0.3 \\
P=0.61\end{array}$ & $\begin{array}{l}\chi^{2}=17.7 \\
P=0.001\end{array}$ & $\begin{array}{l}\chi^{2}=0.1 \\
P=0.71\end{array}$ & 18.8 \\
\hline Elaphropus diabrachys & $\begin{array}{l}\chi^{2}=0.2 \\
P=0.69\end{array}$ & $\begin{array}{l}\chi^{2}=9.3 \\
P=0.002\end{array}$ & $\begin{array}{l}\chi^{2}=21.5 \\
P<0.001\end{array}$ & $\begin{array}{l}\chi^{2}=0.0 \\
\mathrm{P}=1.0\end{array}$ & 35.3 \\
\hline Harpalus affinis & $\begin{array}{l}\chi^{2}=34.9 \\
P<0.001\end{array}$ & $\begin{array}{l}\chi^{2}=8.0 \\
P=0.005\end{array}$ & $\begin{array}{l}\chi^{2}=17.5 \\
\mathrm{P}=0.001\end{array}$ & $\begin{array}{l}\chi^{2}=0.1 \\
P=0.72\end{array}$ & 30.5 \\
\hline Harpalus latus & $\begin{array}{l}\chi^{2}=3.3 \\
P=0.06\end{array}$ & $\begin{array}{l}\chi^{2}=22.5 \\
\mathrm{P}<0.001\end{array}$ & $\begin{array}{l}\chi^{2}=5.2 \\
P=0.27\end{array}$ & $\begin{array}{l}\chi^{2}=0.1 \\
\mathrm{P}=0.78\end{array}$ & 35.0 \\
\hline Harpalus tardus & $\begin{array}{l}\chi^{2}=8.8 \\
P=0.003\end{array}$ & $\begin{array}{l}\chi^{2}=13.8 \\
\mathrm{P}<0.001\end{array}$ & $\begin{array}{l}\chi^{2}=8.3 \\
P=0.08\end{array}$ & $\begin{array}{l}\chi^{2}=1.2 \\
\mathrm{P}=0.28\end{array}$ & 32.4 \\
\hline Lionychus quadrillum & $\begin{array}{l}\chi^{2}=436.4 \\
P<0.001\end{array}$ & $\begin{array}{l}\chi^{2}=72.3 \\
\mathrm{P}<0.001\end{array}$ & $\begin{array}{l}\chi^{2}=47.4 \\
P<0.001\end{array}$ & $\begin{array}{l}\chi^{2}=0.1 \\
P=0.80\end{array}$ & 84.9 \\
\hline Microlestes minutulus & $\begin{array}{l}\chi^{2}=72.2 \\
P<0.001\end{array}$ & $\begin{array}{l}\chi^{2}=2.6 \\
P=0.11\end{array}$ & $\begin{array}{l}\chi^{2}=36.8 \\
P<0.001\end{array}$ & $\begin{array}{l}\chi^{2}=3.9 \\
P=0.05\end{array}$ & 61.0 \\
\hline Philorhizus sigma & $\begin{array}{l}\chi^{2}=0.1 \\
P=0.78\end{array}$ & $\begin{array}{l}\chi^{2}=0.1 \\
P=0.75\end{array}$ & $\begin{array}{l}\chi^{2}=8.8 \\
P=0.07\end{array}$ & $\begin{array}{l}\chi^{2}=0.2 \\
P=0.69\end{array}$ & 8.8 \\
\hline Poecilus versicolor & $\begin{array}{l}\chi^{2}=18.6 \\
P<0.001\end{array}$ & $\begin{array}{l}\chi^{2}=3.6 \\
P=0.05\end{array}$ & $\begin{array}{l}\chi^{2}=8.6 \\
P=0.07\end{array}$ & $\begin{array}{l}\chi^{2}=0.7 \\
\mathrm{P}=0.41\end{array}$ & 40.7 \\
\hline
\end{tabular}

\section{References}

Anderson J, Hanssen O (2005) Riparian beetles, a unique, but vulnerable element in the fauna of Fennoscandia. Biodivers Conserv 14:3497-3524

Bates AJ, Sadler JP, Fowles AP (2006) Condition-dependent dispersal of a patchily distributed riparian ground beetle in response to disturbance. Oecologia 150:50-60

Bednarska AJ, Wyżga B, Mikuś P, Kędzior R (2018) Ground beetle communities in a mountain river subjected to restoration: the Raba River, Polish Carpathians. Sci Total Environ 610-611:1180-1192

Bonn A, Hagen K, Wohlgemuth-von Reiche D (2002) The significance of flood regimes for carabid beetle and spider communities in riparian habitats: a comparison of three major rivers in Germany. River Res Appl 18:43-64

Boscaini A, Franceschini A, Maiolini B (2000) River ecotones: carabid beetles as a tool for quality assessment. Hydrobiologia 422(423):173-181

Bräuer G, Herzog M (1997) Landschaftswandel - Entwicklungsziele in der mit Schadstoffen belasteten Muldeaue. Nat Land Sachs Anhalt 34:47-49

Cartron J-LE, Molles MC, Schuetz JF, Crawford CS, Dahm CN (2003) Ground arthropods as potential indicators of flooding regime in the riparian forest of the Middle Rio Grande, New Mexico. Environ Entomol 32:1075-1084
Cavaillé P, Dommanget F, Daumergue N, Loucougaray G, Spigelberger T, Tabacchi E, Evette A (2013) Biodiversity assessment following a naturality gradient of riverbank protection structures in French prealps rivers. Ecol Eng 53:22-30

Cormier RL, Gardali T, Wood JK (2013) Assessing migratory stopover site quality for birds during fall migration along two California rivers. West $\mathrm{N}$ Am Nat 73:72-79

Denux O, Dauffy-Richard E, Rossi J-P, Augustain S (2017) Rediscovery of the endangered species Harpalus flavescens (Coleoptera: Carabidae) in the Loire River. Insect Conserv Divers 10:488-494

Desender K (2005) A wingless intertidal ground beetle, new to the Belgian fauna, in the river IJzer estuary nature restoration site: Bembidion nigropiceum Marsham, 1802. Belg J Zool 135:95-96

Dufrêne M, Legendre P (1997) Species assemblages and indicator species: the need for a flexible asymmetrical approach. Ecol Monogr 67:345-366

European Environment Agency (EEA) (2018) European Waters Assessment of Status and Pressures. EEA Report No. 7/2018, EEA, Copenhagen

Fournier B, Gillet F, Le Bayon R-C, Mitchell EAD, Moretti M (2015) Functional responses of multitaxa communities to disturbance and stress gradients in a restored floodplain. J Appl Ecol 52:1364-1373

Fox J, Weisberg S (2011) An R companion to applied regression, 2nd edn. Sage, Thousand Oaks

Gerisch M, Schanowski A, Figura W, Gerken B, Dziock F, Henle K (2006) Carabid beetles (Coleoptera, Carabidae) as indicators of 
hydrological site conditions in floodplain grasslands. Int Rev Hydrobiol 91:326-340

Gerisch M, Agostinelli V, Henle K, Dziock F (2012a) More species, but all do the same: contrasting effects of flood disturbance on ground beetle functional and species diversity. Oikos 121:508-515

Gerisch M, Dziock F, Schanowski A, Ilg C, Henle K (2012b) Community resilience following extreme disturbances: the response of ground beetles to a severe summer flood in a central European lowland stream. River Res Appl 28:81-92

Gruppe A, Kilg M, Schopf R (2018) Restoration of a Danube floodplain forest: what happens to species richness of terrestrial beetles? Rest Ecol 26:729-739

Günther J, Assmann T (2005) Restoration ecology meets carabidology: effects of floodplain restitution on ground beetles (Coleoptera, Carabidae). Biodivers Conserv 14:1583-1606

Hauer FR, Locke H, Dreitz VJ, Hebblewhite M, Lowe WH, Muhlfeld CC, Nelson CR, Proctor MF, Rood SB (2016) Gravel-bed river floodplains are the ecological nexus of glaciated mountain landscapes. Sci Adv 2:e1600026

Hering D, Aroviita J, Baattrup-Pedersen A, Brabec K, Buijse T, Ecke F, Friberg N, Gielczewski M, Januschke K, Köhler J, Kupilas B, Lorenz AW, Muhar S, Paillex A, Poppe M, Schmidt T, Schmutz S, Vermaat J, Verdonschot PFM, Verdonschot RCM, Wolter C, Kail J (2015) Contrasting the roles of section length and instream habitat enhancement for river restoration success: a field study of 20 European restoration projects. J Appl Ecol 52:1518-1527

Homburg K, Homburg N, Schäfer F, Schuldt A, Assmann T (2014) Carabids.org: a dynamic online database of ground beetle species traits (Coleoptera, Carabidae). Insect Conserv Divers $7: 195-205$

Jähnig SC, Brunzel S, Gacek S, Lorenz AW, Hering D (2009) Effects of re-braiding measures on hydromorphology, floodplain vegetation, ground beetles and benthic invertebrates in mountain rivers. J Appl Ecol 46:406-416

Januschke K, Verdonschot RCM (2016) Effects of river restoration on riparian ground beetles (Coleoptera: Carabidae) in Europe. Hydrobiologia 769:93-104

Januschke K, Brunzel S, Haase P, Hering D (2011) Effects of stream restorations on riparian mesohabitats, vegetation and carabid beetles. Biodivers Conserv 20:3147-3164

Januschke K, Jähnig SC, Lorenz AW, Hering D (2014) Mountain river restoration measures and their success(ion): effects on river morphology, local species pool, and functional composition of three organism groups. Ecol Indic 38:243-255

Karthe D, Chifflard P, Cyffka B, Menzel L, Nacken H, Raeder U, Sommerhäuser M, Weiler M (2017) Water research in Germany: from the reconstruction of the Roman Rhine to a risk assessment for aquatic neophytes. Environ Earth Sci 76:549

Klaiber J, Altermatt F, Birrer S, Chittaro Y, Dziock F, Gonseth Y, Hoess R, Keller D, Küchler H, Luka H, Manzke U, Müller A, Pfeifer MA, Roesti C, Schneider K, Schlegel J, Sonderegger P, Walter T, Holderegger R, Bergaminin A (2017) Fauna Indicativa. WSL Berichte 54:1-198

Kleiber C, Zeileis A (2018) AER: Applied Econometrics with R. R package version 1.2-6. https://cran.r-project.org/web/packages/ AER/AER.pdf

Kleinwächter M, Rickfelder T (2007) Habitat models for a riparian carabid beetle: their validity and applicability in the evaluation of river bank management. Biodivers Conserv 16:3067-3081

Klemm W, Greif A, Broekaert JAC, Siemens V, Junge FW, van der Veen A, Schultze M, Duffek A (2005) A study on arsenic and the heavy metals in the Mulde River System. Acta Hydrochim Hydrobiol 33:475-491
Laliberté E, Legendre P (2010) A distance-based framework for measuring functional diversity from multiple traits. Ecology 91:299-305

Laliberté E, Legendre P, Shipley B (2015) fd: Measuring functional diversity (FD) from multiple traits, and other tools for functional ecology. R package version 1.0-12. https://cran.r-project.org/web/ packages/FD/FD.pdf

Lambeets K, Vandegehuchte ML, Maelfait J-P, Bonte D (2008a) Understanding the impact of flooding on trait-displacements and shifts in assemblage structure of predatory arthropods on river banks. J Appl Ecol 77:1162-1174

Lambeets K, Hendrickx F, Vanacker S, Van Looy K, Maelfait J-P, Bonte D (2008b) Assemblage structure and conservation value of spiders and carabid beetles from restored lowland river banks. Biodivers Conserv 17:3133-3148

Lambeets K, Vandegehuchte ML, Maelfait J-P, Bonte D (2009) Integrating environmental conditions and functional life-history traits for riparian arthropod conservation planning. Biodivers Conserv 142:625-637

Länderarbeitsgemeinschaft Wasser (Lawa) (1991) Die Gewässergütekarte der Bundesrepublik Deutschland 1990. Hagedornsatz, Berlin

Länderarbeitsgemeinschaft Wasser (Lawa) (2002) Gewässergüteatlas der Bundesrepublik Deutschland - Biologische Gewässergütekarte 2000 - Zustand der Gewässer in Deutschland. Kulturbuchverlag, Berlin

Legendre P, Legendre L (1998) Numerical ecology. Elsevier, Amsterdam

Leyer I, Wesche K (2007) Multivariate Statistik in der Ökologie. Springer, Berlin

Liu Y, Wang Y, Huang H (2006) High interpopulation genetic differentiation and unidirectional linear migration patterns in Myricaria laxiflora (Tamaricaceae), an endemic riparian plant in the Three Gorges Valley of the Yangtze River. Am J Bot 93:206-215

Lorenz AW, Feld CK (2013) Upstream river morphology and riparian land use overrule local restoration effects on ecological status assessment. Hydrobiologia 704:489-501

Lorenz AW, Haase P, Januschke K, Sundermann A, Hering D (2018) Revisiting restored rives reaches: assessing change of aquatic and riparian communities after five years. Sci Total Environ Environ 613-614:1185-1195

McCune B, Grace JB (2002) Analysis of ecological communities. MjM Software Design, Gleneden Beach

Moretti M, Dias ATC, De Bello F, Altermatt F, Chown SL, Azcárate FM, Bell JR, Fournier B, Hedde M, Hortal J, Ibanez S, Öckinger E, Sousa JP, Ellers J, Berg MP (2017) Handbook of protocols for standardized measurement of terrestrial invertebrate functional traits. Funct Ecol 31:558-567

Müller-Motzfeld G (2006) Band 2, Adephaga 1: Carabidae (Laufkäfer). In: Lohse GA, Klausnitzer B (eds) Freude H, HardeKW. Die Käfer Mitteleuropas. Spektrum, Heidelberg

Naiman RJ, Decamps H, Pollock M (1993) The role of riparian corridors in maintaining regional biodiversity. Ecol Appl 3:209-212

Nobis A, Rola K, Węgrzyn M (2017) Detailed study of a river corridor plant distribution pattern provides implications for river valley conservation. Ecol Indic 83:314-322

Oksanen J, Guillaume Blanchet F, Friendly M, Kindt R, Legendre P, McGlinn D, Minchin PR, O'Hara RB, Simpson GL, Solymos P, Stevens MHH, Szoecs E, Wagner H (2019) vegan: Community Ecology Package. R package version 2.5-4. https://CRAN.Rproj ect.org/package $=$ vegan

Paetzold A, Yoshimura C, Tockner K (2008) Riparian arthropod responses to flow regulation and river channelization. J Appl Ecol 45:894-903

Paillex A, Schuwirth N, Lorenz AW, Januschke K, Peter A, Reichert $P$ (2017) Integrating and extending ecological river assessment: 
concept and test with two restoration projects. Ecol Indic 72:131-141

Puhlmann G, Rast G (1997) Zum Feststoffhaushalt der Mulde im Raum Sachsen-Anhalt - Zustand, Perspektiven und Handlungsempfehlungen aus ökomorphologischer Sicht. Nat Land Sachs Anhalt $34: 33-37$

R Core Team (2018) R: a language and environment for statistical computing. R Foundation for Statistical Computing, Vienna, Austria. https://www.R-project.org/

Reichhoff L, Refior K (1997) Der Naturraum der unteren Mulde und seine Nutzung. Nat Land Sachs Anhalt 34:3-11

Roberts DW (2016) labdsv: Ordination and Multivariate Analysis for Ecology. R package version 1.8-0. https://cran.r-project.org/web/ packages/labdsv/labdsv.pdf

Romanowski J, Brzeziński M, Żmihorski M (2013) Habitat correlates of the Eurasian otter Lutra lutra recolonizing Central Poland. Acta Theriol 58:149-155

Rothenbücher J, Schaefer M (2006) Submersion tolerance in floodplain arthropod communities. Basic Appl Ecol 7:398-408

Rumm A, Foeckler F, Deichner O, Scholz M, Gerisch M (2016) Dykeslotting initiated rapid recovery of habitat specialists in floodplain mollusc assemblages of the Elbe River, Germany. Hydrobiologia 771:151-163

Rumm A, Foeckler F, Dziock F, Ilg C, Scholz M, Harris RMB, Gerisch M (2018) Shifts in mollusc traits following floodplain reconnection: Testing the response of functional diversity components. Freshw Biol 63:505-517

Sadler J, Bell D, Fowles A (2004) The hydroecological controls and conservation value of beetles on exposed riverine sediments in England and Wales. Biol Conserv 118:41-56

Schindler S, O’Neill FH, Biró M, Damm C, Gasso V, Kanka R, van der Sluis KA, Lauwaars SG, Sebesvari Z, Pusch M, Baranovsky B, Ehlert T, Neukirchen B, Martin JR, Euller K, Mauerhofer V, Wrbka T (2016) Multifunctional floodplain management and biodiversity effects: a knowledge synthesis for six European countries. Biodivers Conserv 25:1349-1382

Schirmel J, Bundschuh M, Entling M, Kowarik I, Buchholz S (2016) Impacts of invasive plants on resident animals across ecosystems, taxa, and feeding types: a global assessment. Glob Change Biol 22:594-603

Schmidt J, Trauntner J, Müller-Motzfeld G (2016) Rote Liste und Gesamtartenliste der Laufkäfer (Coleoptera: Carabidae) Deutschlands. 3. edition, version April 2015. In: Bundesamt für Naturschutz (ed): Rote Liste gefährdeter Tiere, Pflanzen und Pilze Deutschlands. Wirbellose Tiere Teil 2. Naturschutz und Biologische Vielfalt 70:139-204

Schnitter P, Trost M (2004) Rote Liste der Laufkäfer (Coleoptera: Carabidae) des Landes Sachsen-Anhalt. Ber Landesamtes Umweltschutz Sachs Anhalt 39:252-263

Schnitter P, Grill E, Trost M (2001) 4.2.2.16 Laufkäfer (Carabidae). In: LAU - Landesamt für Umweltschutz Sachsen-Anhalt (ed) Artenund Biotopschutzprogramm Sachsen-Anhalt. Landschaftsraum Elbe. Ber Landesamtes Umweltschutz Sachs Anhalt Sonderheft 2001, Part 2:390-403
Scholz M, Rupp H, Puhlmann G, Ilg C, Gerisch M, Dziock F, Follner K, Foeckler F, Glaeser J, Konjuchow F, Krüger F, Regner A, Schwarze A, von Tümpling W, Duquesne S, Liess M, Werban U, Zacharias S, Henle K (2016) Deichrückverlegungen in SachsenAnhalt und wissenschaftliche Begleituntersuchungen am Beispiel des Roßlauer Oberluchs. Nat Land Sachs Anhalt 46:103-115

Schulz-Zunkel C, Rast G, Schrenner H, Baborowski M, Bauth S, Bondar-Kunze E, Brauns M, Bromberger S, Dziock F, Gapinski C, Gründling R, von Haaren C, Hein T, Henle K, Kamjunke N, Kasperidus HD, Koll K, Kretz L, Krüger F, Möws R, Otte M, Pucher M, Schmidt C, Schnauder I, Scholz M, Seele C, Nogueira Tavares C, von Tümpling W, Vieweg M, Warthemann G, Weitere M, Wirth C (2017) Wilde Mulde - Revitalisierung einer Wildflusslandschaft in Mitteldeutschland. Nat Land Sachs Anhalt 54:46-65

Sienkiewicz P, Zmihorski M (2011) The effect of disturbance caused by rivers flooding on ground beetles (Coleoptera: Carabidae). Eur J Entomol 109:535-541

Smith EP (2002) BACI design. In: El-Shaarawi AH, Piegorsch WW (eds) Encyclopedia of environmetrics, vol 1. Wiley, Chichester, pp 141-148

Sneddon CS, Barraud R, Germaine M-A (2017) Dam removals and river restoration in international perspective. Water Altern 10:648-654

Stewart-Oaten A, Murdoch WW, Parker KR (1986) Environmental impact assessment: pseudoreplication in time? Ecology 67:929-940

Stockan JA, Baird J, Langan SJ, Young MR, Iason GR (2014) Effects of riparian buffer strips on ground beetles (Coleoptera, Carabidae) within an agricultural landscape. Insect Conserv Divers 7:172-184

Strayer DL, Dudgeon D (2010) Freshwater biodiversity conservation: recent progress and future challenges. Freshw Sci 29:344-358

Thurow A (2016) Zur Laufkäferfauna (Coleoptera: Carabidae) natürlicher Uferstrukturen der Unteren Mulde. Nat Land Sachs Anhalt 53:55-63

Van Looy K, Vanacker S, Jochems H, de Blust G, Dufrêne M (2005) Ground beetle habitat templets and riverbank integrity. River Res Appl 21:1133-1146

Villéger S, Mason NWH, Mouillot D (2008) New multidimensional functional diversity indices for a multifaceted framework in functional ecology. Ecology 89:2290-2301

Warthemann G, Wölfel U (1997) Flora und Vegetation der Muldeaue. Nat Land Sachs Anhalt 34:47-49

Zuppke U, Jurgeit F (1997) Tierwelt der Muldeaue. Nat Land Sachs Anhalt 34:47-49

Zuur AF, Ieno EN, Walker NJ, Saveliev AA, Smith GM (2009) Mixed effects models and extensions in ecology with R. Springer, New York

Publisher's Note Springer Nature remains neutral with regard to jurisdictional claims in published maps and institutional affiliations. 